\title{
Hsa_circ_0015326 Promotes the Proliferation, Invasion and Migration of Ovarian Cancer Through miR-I 27-3p/MYB [Retraction]
}

Zhang C, Liu W, Li F, Feng Y, Li Y, Wang J. Cancer Manag Res. 2021;13:2265-2277.

At the authors request, the Editor and Publisher of Cancer Management and Research wish to retract the published article. The authors have advised they are unable to reproduce the results described from this study and believe the data reported to be invalid. In addition, the authors are unable to locate the original data for their study. The Editor has agreed with the decision to retract the article.

Our decision-making was informed by our policy on publishing ethics and integrity and the COPE guidelines on retraction.

The retracted article will remain online to maintain the scholarly record, but it will be digitally watermarked on each page as "Retracted".

\section{Publish your work in this journal}

Cancer Management and Research is an international, peer-reviewed open access journal focusing on cancer research and the optimal use of preventative and integrated treatment interventions to achieve improved outcomes, enhanced survival and quality of life for the cancer patient.
The manuscript management system is completely online and includes a very quick and fair peer-review system, which is all easy to use. Visit http://www.dovepress.com/testimonials.php to read real quotes from published authors. 